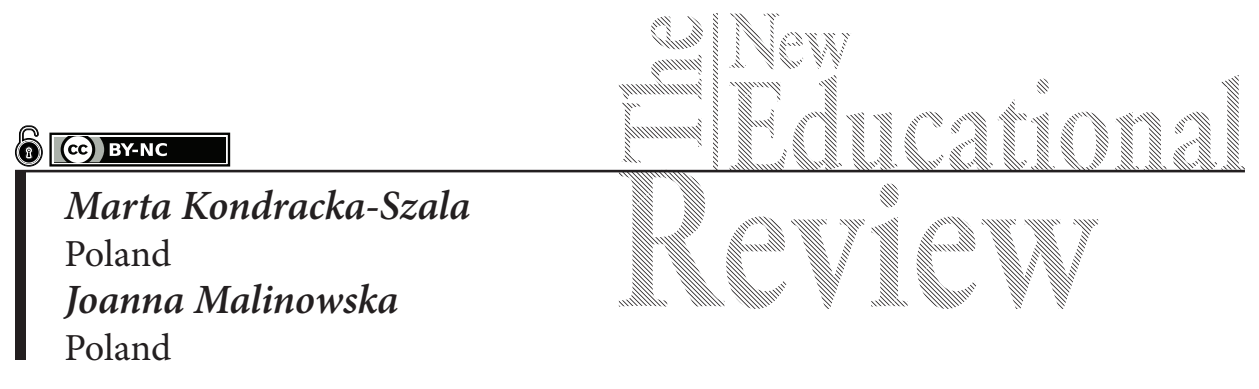

\title{
Entrepreneurship Education as a Challenge in the Education of Teachers of Pre-school and Early School Children - at the Intersection of Academic Theory and Practice
}

DOI: $10.15804 /$ tner.2019.58.4.12

\begin{abstract}
:
This article refers to entrepreneurship as a key skill. It presents the components of the innovative concept of kindergarten and early school teacher training in this area, which has been carried out since the academic year 2019/2020 at the Institute of Pedagogy of the University of Wrocław. It introduces the reconstruction of the meaning attached to the notion of entrepreneurship in the Finnish approach using the method of semantic field analysis, which has been the basis for the development of these assumptions.
\end{abstract}

Key words: entrepreneurship education, teacher education, children education, semantic field analysis

\section{Introduction}

The European Commission has recognized entrepreneurship as one of the key competences, which comprises the knowledge, skills and attitudes necessary to generate innovative ideas and apply them effectively ${ }^{1}$. Entrepreneurship is also

\footnotetext{
${ }^{1}$ Council Recommendation of 22 May 2018 on key competences for lifelong learning (Text relevant for EEA) (2018/C 189/01), source: https://eur-lex.europa.eu/legal-content/PL/TXT/ $\mathrm{PDF} /$ ?uri=CELEX:32018H0604(01)\&from=en (1.02.2019).
} 
a competence of the $21^{\text {st }}$ century teacher. A teacher's entrepreneurship manifests itself in the design and implementation of an alternative educational program, the use of original solutions in didactic and educational work, awareness of the current trends and new directions in education, as well as the cultural, economic and social contexts of the child's/student's living conditions.

Many authors who have provided insights into the topic of entrepreneurship education (enterprise education) ${ }^{2}$ point out that the development of traits and skills that foster the entrepreneurial spirit and entrepreneurial attitude should start from an early age. However, the literature on the subject indicates that any changes in education, any reforms or curriculum modifications in the area of entrepreneurship education should focus more on changes in teacher training than in the education of students and pupils. In entrepreneurship education, it is the teacher who should play the central role (Seikkula-Leino, Ruskovaara, Ikavalko, Mattila, \& Rytkola, 2010). Bearing this in mind, suitable preparation of kindergarten teachers and primary teachers of first to third grade children for conducting entrepreneurship education classes becomes a requirement and a challenge.

The development of the conception of preparing students, future teachers of kindergartens and grades from one to three, for the implementation of entrepreneurship education classes was a multi-stage process. The groundwork for the project was contextual analysis (done as part of the empirical research carried out by the authors of this article between 2015 and 2017), i.e. a study of the assumptions and execution of entrepreneurship education in Europe, mainly with regard to teacher training, but also child/pupil education (Kondracka-Szala \& Malinowska, 2017). The first stage of the work was reconstruction of the meaning given to the term 'entrepreneurship' in the Finnish model of entrepreneurship education (Ruskovaara, Pihkala \& Lahikainen, 2018; Ruskovaara, Hämäläinen \& Pihkala, 2016; Korhonen, Komulainen \& Räty, 2012)3.

2 https://www.qaa.ac.uk/docs/qaas/enhancement-and-development/enterprise-and-entrpreneurship-education-2018.pdf?sfvrsn=15f1f981_8 (1.07.2019) see also: Directorate-General for Enterprise and Industry (European Commission), Hilfe zum Aufbau einer unternehmerischen Kultur Leitfaden zu bewährten Verfahren bei der Förderung unternehmerischer Grundeinstellungen und Kompetenzen durch Bildungsmaßnahmen, 2004, https://publications.europa.eu/en/ publication-detail/-/publication/98912089-1cff-4f51-ab71-a3d422804a5c/language-de\#.

3 In the Finnish education system, entrepreneurship education is combined with active and participatory citizenship. This is reflected in the education curricula at all stages of education. Entrepreneurship education is also strongly emphasized in academic education: Guidelines for entrepreneurship education, Ministry of Education, Department for Education and Science, Finland 2009 http://www.minedu.fi/export/sites/default/OPM/Julkaisut/2009/liitteet/opm09. pdf (05.04.2019). 
In order to capture the contexts of application and use of the term, discourse analysis and the particular variation, semantic field analysis, were used.

\section{Research Methods}

Discourse is an ambiguous concept which is used in many scientific disciplines and non-scientific areas. This explains the difficulty of clearly defining its essence. The multiplicity of interpretations makes discourse a vague concept, thus, it is necessary to specify it in order to adopt a correct research procedure. It has been assumed, in accordance with Joanna Malinowska's theory, that the semantic scope of discourse includes an element of a clash of arguments, interpretation of meanings and multiplication of alternatives supported by arguments. In this way, views and opinions are revealed, meanings are conveyed, events are decided and their rank of importance is set (Malinowska, 2017).

For the purposes of this empirical study, we have adopted the definition that 'discourse is a text in context' (van Dijk, 1990, pp. 133-156; Gee, 2011). The authors take the view that a linguistic utterance (written, oral), or discourse, should be perceived as a process, and not just as a result of communication. The interactivity of language communication and the genesis of language meanings make up the context of speech, which is also associated with the assumptions and beliefs of the authors of that speech/discourse (Johnstone, 2018). Discourse analysis is, therefore, an analysis of concepts, ideas and assumptions conveyed in texts and utterances, the purpose of which is to examine and describe the relationship between the users' language and thinking. Hence, it is important that, in this sense, discourse analysis accounts for 'transtextual' language phenomena (social roles, attitudes, beliefs of discourse actors (Topczewska, 2017, p. 50). Thus, language allows us to name educational situations, to develop our own ideas of future actions, intentions, and to transfer knowledge about the world.

Semantic field analysis, as an element of linguistic discourse analysis, explores language as a social fact, i.e. an intentional action that affects the recipient (Topczewska, 2017, p. 49). The methodological setting of the study was based on Regine Robin's theory (Guilhaumou, Maldidier, \& Robin, 1994) and specified by Marek Kłosiński (1994). According to this researcher, semantic field analysis is 'an analysis of a key concept in the discourse that has been verbalized by means of a key-word' (Kłosiński, 1994, p. 152).

We analysed the report entitled Mapping of teachers'preparation for entrepreneurship education. Final Report (Curth, 2011), which overviews the Finnish concept 
of preparing teachers for entrepreneurship education. The assumptions contained therein relate to activities undertaken by academic teachers who conduct the classes, as well as to the addressees of these classes and other persons involved in this type of education. The subject of our research is the meaning given to the term entrepreneurship by the authors of this concept. The method used to analyse the semantic field, which analysed all applications and contexts of the use of the term 'entrepreneurship', facilitates identification of its meaningful readability (Guilhaumou, Maldidier \& Robin, 1994). A semantic field of a given concept is a network of its connections with other words, expressions, and ideas that appear in the analysed text. The thematic or conceptual relationships and the functions performed by the phrases and actions used in the text make it possible to understand the full meaning of the concept, or the group of meanings in which it was used (Curth, 2011).

We adopted a three-stage research procedure. The first step was to create six sets of terms related to entrepreneurship. For this purpose, we searched for words that:

1. describe the concept of entrepreneurship, and show its features - a set of terms was constructed in this way,

2. are associations, which include concepts accompanying entrepreneurship,

3. are terms opposite to the concept of entrepreneurship,

4. replace the concept of entrepreneurship, so are its equivalents,

5. describe how entrepreneurship works and what effects it triggers,

6. describe the actions that should be taken towards entrepreneurship as a subject.

The next step was to organize these terms and place them in a network of relationships that reveal the semantic field of the term entrepreneurship. Thanks to this, we gained insight into how the examined concept is perceived and represented. The last step in the research process was to reconstruct the meaning of the term entrepreneurship.

\section{Research Results}

As a result of the research procedure employed, it has been inferred that in the Finnish approach, entrepreneurship is a social phenomenon; it is a combination of business knowledge, various skills and competences, such as: independence, problem solving, initiative, and creativity; Entrepreneurship is equated to being an active citizen, a participating citizen. Entrepreneurship is associated with: cultivating the entrepreneurial spirit, as well as social requirements and requirements set by employers. Entrepreneurship consists in: transferring and passing on positive attitudes, approaches and creating a positive image of entrepreneurship in society. 
The following activities are undertaken for the sake of entrepreneurship: bringing about a change in attitudes among teachers and students, analysing entrepreneurship teaching programs in schools, encouraging cooperation between various entities (school, university, entrepreneur), combining theoretical studies, meeting entrepreneurs and experiencing practical projects, introducing and improving work tools and methods, providing knowledge, skills, attitudes and values. The diagram below illustrates the network of terms used in the document which was analysed.

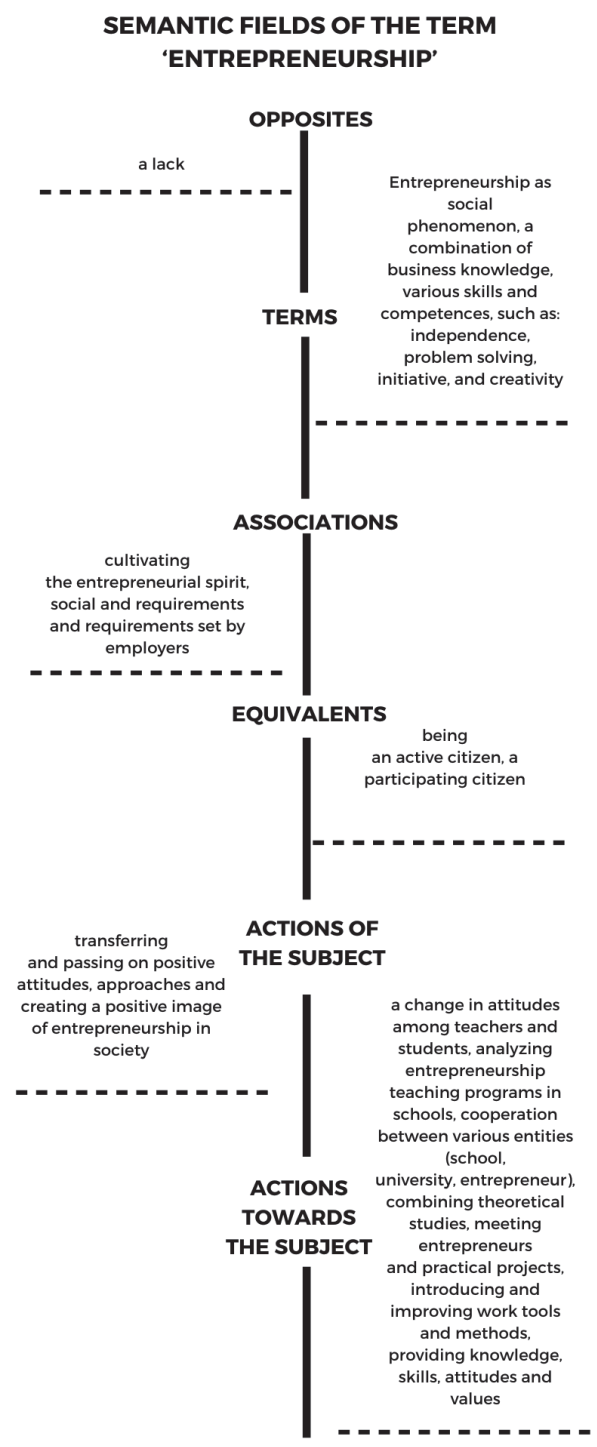

Figure 1. Semantic field of the concept of entrepreneurship Source: own research. 
Following Marek Kłosiński's guidelines, a declarative sentence structure (presented in Table 1) was adopted, which allows the reconstruction of the meaning of the studied concept of entrepreneurship (key-word), i.e. equivalents, are terms that are linked with associations that cause/effect actions of the subject for/to/against whom action should be taken towards the subject (Kłosiński, 1994, p. 151).

Table 1. Semantic field - keyword

\begin{tabular}{ll}
\hline & KEYWORD, \\
\hline so & equivalents \\
\hline as opposed to & opposites \\
\hline is & terms \\
\hline is associated with & associations \\
\hline which causes & actions of the subject \\
\hline towards whom one should & actions towards the subject \\
\hline
\end{tabular}

Own model based on. M. Kłosiński, (1994, 3, p. 155).

Using this model, two logically consistent and grammatically correct sentences were constructed, which become the basis for the reconstruction of the meaning contained in the document analysed:

1. Entrepreneurship or active citizenship is a social phenomenon that is associated with the spirit of entrepreneurship, which results in the transmission of positive attitudes and values and to achieve this goal, one must analyse entrepreneurship teaching programs, and introduce and improve work tools and methods by combining theoretical studies, meetings with entrepreneurs and practical projects.

2. Entrepreneurship, i.e. being a participating citizen, is a combination of business knowledge, various skills and competences, associated with social requirements, which leads to a positive image of entrepreneurship in society, which requires development of knowledge, skills and attitudes and values as well as cooperation between various entities: schools, universities, and entrepreneurs.

The above analysis shows that the Finnish concept of entrepreneurship has a strong social and civic orientation. As a consequence, entrepreneurship is connected with the activity of citizens and their participation in social life. It is a desirable social phenomenon based on multifaceted cooperation and the creation of a positive image of entrepreneurship and entrepreneurial education. The analysis also allows us to draw conclusions about the role of the teacher as a professional, reflective practitioner and promoter of entrepreneurship competences among children/pupils. 


\section{Discussion}

The analysis presented above was the starting point for the development of the concept of how to prepare an early childhood education teacher for conducting entrepreneurship education classes. In the Polish context, this is a departure from the narrow understanding of entrepreneurship, towards social and civic entrepreneurship. In this interpretation, entrepreneurship education cannot be limited to providing information necessary to understand how the social world works, nor is its goal to adapt a person to life in society, but rather to prepare him or her for active participation in social life. So defined, entrepreneurship education becomes a component of civic education. As Poles are, in comparison with other European nations, a poorly socialized society, with a low sense of community, this is undoubtedly a challenge for education. The inhibiting factor is the limited involvement, and the withdrawal of young people from public and civic activities. The teacher is perceived by the authors of this paper as a medium for shaping the positive attitude of students towards entrepreneurship, activity and participation in social life. It is hence necessary to ask what educational efforts by the teacher can promote a change of attitude and encourage children's engagement in public affairs. The goal is also to change the perception of the pupil/student for the future: as a citizen and entrepreneurial person, which involves adopting a specific style of group/class management (Orstein, 1990).

The final conception of educating students in the university major courses: Pre-School and Early School Education is to support the training of teachers in kindergartens and in grades one to three in the field of nurturing the spirit and attitude of entrepreneurship, as well as to prepare them for conducting entrepreneurship lessons. Entrepreneurship education along with Educational Leadership in Teacher's Work are mandatory courses and constitute a coherent whole. The primary objective is to steer the thinking and actions of students towards enhancing entrepreneurial activity in the local community, to undertake ventures preceded by thoughtful analysis of the contexts of action and to improve practice/organization by introducing innovations. It is to encourage teachers to break the monotony of routine instructional methods, and to sensitize them to the need to respond to changes occurring inside and outside the organization.

Therefore, the concept refers to the teacher's self-development in two areas: his or her own entrepreneurship competence and the ability to develop the basic characteristics of this competence in children and students. When it comes to the first area, the Finnish model of entrepreneurship education was the benchmark (Ruskovaara, Pihkala \& Lahikainen, 2018; Ruskovaara, Hämäläinen, Pihkala, 2016; 
Korhonen, Komulainen, Räty \& 2012). As for the second area, the EntreComp model, The Entrepreneurship Competence Framework (Bacigalupo, Kampylis, Punie \&Van den Brande, 2016), was used.

The implementation of this model is based on solutions designed to improve the quality of education in terms of content and methods. The courses incorporated into the university curriculum help prepare the graduate for the role of a teacher: a researcher, reflective practitioner, leader of school and local communities, initiator of changes, and an animator of social and entrepreneurial activity. Therefore, there is a dual aspect to them, with a clear focus on elements of education about entrepreneurship and education for entrepreneurship.

Consequently, the program puts emphasis on entrepreneurship as a key competence, on the conditions for its acquisition/improvement, the theoretical premises of entrepreneurship education and proposals for classes and exercises, which may contribute to undertaking entrepreneurial activities and creating a new quality of education inside the institution (the future workplace of the kindergarten or school teacher). For this purpose, it is planned to cast external stakeholders in the role of partners and consultants, thus creating opportunities for learning through action and in interaction with various participants/entities in the local community, as we must keep in mind that the entrepreneurial attitude is shaped through action and in connection with civic engagement in the local area. The experience gathered this way can be a blueprint for making conscious choices and for the capacity to predict their consequences. The environment in which the teacher works often determines these choices, but also raises questions about the possibility of bringing about change and the direction of this change. Thus, based on this, only the solutions about which the teachers are already strongly convinced are effective in introducing change should be chosen, and when there are no ready-made solutions, new ways and tools for influencing the situation should be developed. Entrepreneurial behaviours consist in an unremitting analysis of the current situation of the education system and in choosing/ creating solutions.

An enterprising teacher should also take an active attitude related to democratic empowerment. Students will have the opportunity to develop their own skills in the area of internal/personal entrepreneurship; they will be encouraged to reflect on themselves as a promoter of changes, while taking into account the perspective of the competent teacher.

The program which is designed on these principles is not a list of issues for discussion: it focuses on problems that one can observe/diagnose, and then look for solutions and test them. Study visits to selected institutions are planned (kin- 
dergartens and democratic schools, kindergartens and independent schools). The professional knowledge gained during intense interactions, while learning from each other, will become a capital that can contribute to high-quality entrepreneurship education for students. Below are selected tasks for students to implement as part of the problems:

Problems: Kindergarten/school as a space for joint participation of children and adults. The teacher as an instigator of changes, active in society and for society

1. Comparative analysis of the curriculum of a selected kindergarten/ school with the curriculum of the study visit school, including:

a) participation of parents/other adults and participation of children in decision-making processes as signs of the implementation of the idea of active and participatory citizenship;

b) initiatives/activities/working methods to carry out the principles of entrepreneurship education;

c) combining various forms of education: formal, non-formal and informal to meet the objectives of entrepreneurship education.

Work in pairs: analyse documents, websites, interviews with teachers, interviews with parents, observation. Student presentations to compare teaching programs.

2. Constructing an alternative educational program for kindergarten/ school, including:

a) thinking about children as active citizens;

b) departure from thinking about childhood as a period of preparing children for 'real' life and 'granting' rights to them according to criteria set by adults;

c) a change in the approach to civic education (which today is reduced to 'material to be learned', which makes it similar to other courses). This education is isolated from practice.

Therefore, the independent alternative curriculum should:

1) construe civic education as a social task (with designated roles/tasks for parents, teachers and other adults), focused on the acquisition/development/improvement of civic competences in the course of action;

2) promote children's participation, defined as involving children in decision-making processes;

3) account for the fact that children/students are gaining knowledge and experience outside institutions today. Both non-formal and informal education often have a greater impact on the development of a learner's personality than does the institutional environment; 
4) take into consideration the growing interest of parents in an educational alternative to the traditional school;

5) be embedded within the socio-cultural context of the local kindergarten/school environment.

Work in groups: Development of a coherent teaching program for a selected age group.

3. Discussing the possibilities of introducing the agreed changes with the teachers of the selected kindergarten/school. Development and implementation of an idea using the design thinking method.

\section{Conclusions}

Nurturing the entrepreneurial spirit becomes an opportunity for the development of individual and social education participants. A critical look at entrepreneurship education seems to be inspiring here. The efforts to strengthen and develop the entrepreneurial spirit as part of a collective effort have not only social consequences.

Entrepreneurship education involves discovering the relationship between education and provocation. An entrepreneurship education teacher should work in a space that allows disagreement, provides an arena where other ways of thinking and understanding can flourish, and which encourages invention (Hjorth, 2011, pp. 49-63). Priority should be given to deconstructing and rebuilding, (to which a debate often leads), to sharing ideas, and creating a common, different educational space.

Preparing future teachers for conducting entrepreneurship education defined this way is also a challenge for those implementing this concept, especially in view of the need to claim the emancipatory potential of academic education, which will allow university students to start thinking about children as active citizens.

A change in teacher education should, therefore, occur in four interrelated areas.

Fostering the entrepreneurial spirit (1) requires the preparation of future teachers to act as promoters and initiators of change (2), and as local community leaders (3). This suggests the need to develop a new approach and new model of cooperation between education participants (4). Teaching internships and study visits are a space for such cooperation between teacher-practitioners, students and academic teachers, in which the academic teachers become consultants and co-creators of educational projects and 'critical friends' for the students carrying them out. 


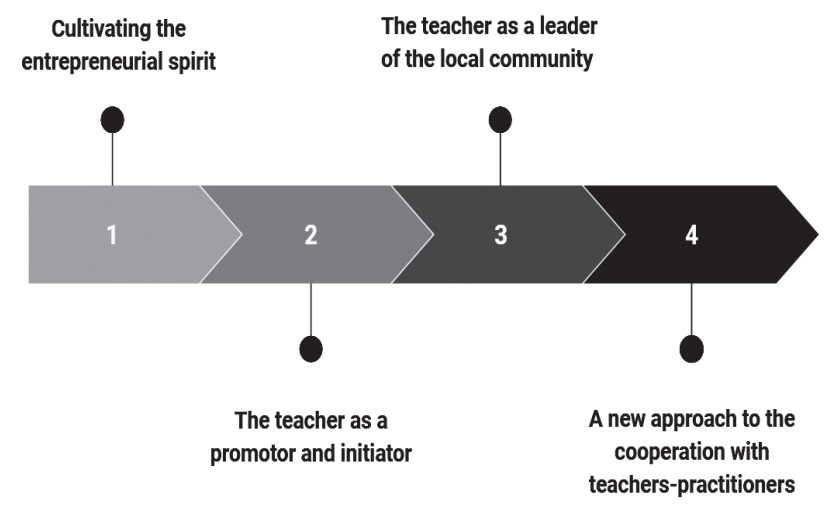

Figure 2. Areas of changes in the approach to teacher education in kindergarten and early school education. Source: own study

The adoption of a broad and critical understanding of entrepreneurship (Berglund \& Verduijn, 2018, p. 13) suggests that this competence can be a way to freedom and creativity, thus meeting the challenges of today.

\section{Bibliography}

Bacigalupo, M., Kampylis, P., Punie. Y., Brande, \& G. Van den. (2016). EntreComp: The Entrepreneurship CompetenceFramework. Luxembourg: Publication Office of the European Union; EUR 27939 EN; Retrieved 15/02/2019, from:: http://publications.jrc. ec.europa.eu/repository/bitstream/JRC101581/lfna27939enn.pdf .

Berglund, K., \& Verduijn, K. (2018). Introduction: Challenges for entrepreneurship education. In: Berglund, K., \& Verduijn, K. (Eds.), Revitalizing Entrepreneurship Education: Adopting a Critical Approach in the Classroom. (pp.3-24). London: Routledge.

Curth, A. (2011), Mapping of teachers' preparation for entrepreneurship education. Final Report, Retrieved 01/07/2019, from: https://www.ab.gov.tr/files/ardb/evt/1_avrupa_ birligi/1_9_politikalar/1_9_4_egitim_politikasi/mapping_en.pdf

Dijk T.A. van. (1990). The future of the field: Discourse analysis in the 1990s. Text, 10, 133-156.

European Innovation Scoreboard. (2018). Retrieved 20/03/2019, from: https://ec.europa. eu/growth/content/european-innovation-scoreboard-2018-europe-must-deepen-its-innovation-edge_en.

Gee, J.P. (2011). How to do Discourse Analysis: A Toolkit. New York: Routledge. Retrieved 
10/10/2019, from: http://105.235.201.125/Linguistic/How\%20to\%20do\%20Discourse\%20Analysis,\%20A\%20Toolkit.pdf

Guilhaumou, J., Maldidier, D., \& Robin, R. (1994). Discours et archive: expérimentations en analyse $d u$ discours. Paris: Mardaga.

Hjorth, D. (2011), On provocation, education and entrepreneurship. Entrepreneurship \& Regional Development, 23, 49-63.

Johnstone, B. (2018). Discourse analysis. Hoboken, NJ: John Wiley \& Sons.

Kłosiński, M. (1994). Semantyczna analiza pojęć "bezrobocie” i "bezrobotny” („ bezrobotni”) w wypowiedziach prasowych [Semantic Analysis of Terms 'Unemployment' and 'Unemployed' in Press Releases], Kultura i społeczeństwo, 38(3).

Kondracka-Szala, M., \& Malinowska, J. (2017). Entrepreneurship as the key competence of early education teachers in the context of employers' expectations - research report. The New Educational Review, 49(3), 239-249.

Korhonen, M., Komulainen, K., \& Räty, H. (2012). Not everyone is cut out to be the entrepreneur type: How Finnish school teachers construct the meaning of entrepreneurship education and the related abilities of the pupils. Scandinavian Journal of Educational Research, 56(1), 1-19.

Malinowska, J. (2017). Change of students' activities in the process of becoming a teacher. Andragoška spoznanja, 23(3), 92.

Ornstein, A.C. (1990). Strategies for Effective Teaching. New York: Harper Collins.

Ruskovaara, E., Hämäläinen, M., \& Pihkala, T. (2016). Head teachers managing entrepreneurship education-Empirical evidence from general education. Teaching and Teacher Education, 55, 155-164.

Ruskovaara, E., Pihkala, T., \& Lahikainen, K. (2018). European approaches to enterprise education. In Turner, J.J. \& Mulholland, G. (Eds.) International Enterprise Education: Perspectives in theory and practice (pp. 1-22). London: Routledge.

Seikkula-Leino, J., Ruskovaara, E., Ikavalko, M., Mattila, J., Rytkola, T. (2010). Promoting entrepreneurship education: the role of the teacher?, Education+ training, 52(2), 117-127.

Topczewska, U. (2017). Analiza pola semantycznego jako metoda badania dyskursu [Semantic Field Analysis as a Method of Discourse Research]. In: Czyżewski, M., Otrocki, M., Piekot, T. et al. (eds), Analiza dyskursu publicznego. Przeglad metod i perspektyw badawczych [Analysis of Public Discourse: A Review of Research Methods and Perspectives], Warszawa: Sedno. 